\title{
THE GENETICS OF AMELOGENESIS IMPERFECTA. A REVIEW OF THE LITERATURE
}

\author{
GENÉTICA DA AMELOGÊNESE IMPERFEITA - UMA REVISÃO DA LITERATURA
}

\author{
Maria Cristina Leme Godoy dos SANTOS', Sergio Roberto Peres LINE²
}

1- PhD student, Piracicaba Dental School, , State University of Campinas - UNICAMP.

2- PhD, Piracicaba Dental School, State University of Campinas - UNICAMP.

Corresponding address: Maria Cristina Leme Godoy dos Santos, Faculdade de Odontologia de Piracicaba/UNICAMP, Departamento de Morfologia, Av. Limeira, 901, CP 52, CEP 13414-903, Piracicaba-SP, Brazil, Phone: +55-019-34125333, Fax: +55-019-34125218 e-mail: mariacristina@fop.unicamp.br

Received: April 08, 2005 - Modification: June 06, 2005 - Accepted: June 06, 2005

\begin{abstract}
A

melogenesis imperfecta (AI) is a group of inherited defects of dental enamel formation that show both clinical and genetic heterogeneity. Enamel findings in AI are highly variable, ranging from deficient enamel formation to defects in the mineral and protein content. Enamel formation requires the expression of multiple genes that transcribes matrix proteins and proteinases needed to control the complex process of crystal growth and mineralization. The AI phenotypes depend on the specific gene involved, the location and type of mutation, and the corresponding putative change at the protein level. Different inheritance patterns such as X-linked, autosomal dominant and autosomal recessive types have been reported. Mutations in the amelogenin, enamelin, and kallikrein-4 genes have been demonstrated to result in different types of AI and a number of other genes critical to enamel formation have been identified and proposed as candidates for AI. The aim of this article was to present an evaluation of the literature regarding role of proteins and proteinases important to enamel formation and mutation associated with AI.
\end{abstract}

Uniterms: Amelogenesis imperfecta; Mutation; Enamel protease; Enamel proteinase.

\section{RESUMO}

\begin{abstract}
A melogênese imperfeita é um grupo de doenças hereditárias que causa defeito na formação esmalte dental e mostra heterogeneidade clínica e genética. O esmalte é afetado com alta variabilidade, desde deficiência na formação do esmalte até defeitos no conteúdo mineral e protéico. A formação do esmalte requer a expressão de múltiplos genes que transcrevem proteínas e proteinases importantes para controlar o complexo processo de crescimento dos cristais e mineralização. O fenótipo da AI depende do gene envolvido, sua localização e tipo de mutação, e a conseqüente alteração na proteína. Diferentes padrões hereditários com ligado ao X, autossômico dominante e autossômico recessivo já foram descritos. Mutações nos genes correspondentes da amelogenina, enamelina, e calicreína-4 demonstraram resultar em diferentes tipos de AI. Outros genes críticos para formação do esmalte estão sendo identificados como candidatos a causar AI. O objetivo desse artigo foi investigar na literatura o papel de proteínas e proteinases importantes para formação do esmalte e mutações associadas a AI. Unitermos: Amelogênese imperfeita; Mutações; Proteínas do esmalte.
\end{abstract}

\section{INTRODUCTION}

Dental enamel, the most highly mineralized structure in the human body, is formed within a unique, extracellular matrix derived through the synthesis and secretion of proteins by the ameloblast cells. Dental enamel differs from other mineralized tissues, such as bone, cartilage and dentine, in that it is noncollagenous, originated from epithelium, and does not undergo resorption and remodeling ${ }^{16}$.
Dental enamel formation is divided into secretory, transition, and maturation stages ${ }^{56}$. During the secretory stage, enamel crystals grow primarily in length. The crystallites lengthen at a mineralization front formed near the secretory surfaces of the ameloblast cell. During the maturation stage, mineral is deposited exclusively on the sides of the crystallites, which grow in width and thickness to coalesce with adjacent crystals. The arrangement of ions in dental enamel crystals closely approximates that of 
calcium hydroxyapatite. Sketched out in the protein matrix, the hidroxyapatite crystal architecture continues to grow in width and thickness due to a progressive protein hydrolysis ${ }^{56}$.

The deposition of enamel crystals is encoded in the genetic blueprint, whose instructions are mediated by the activities of proteins ${ }^{56}$. The main structural proteins in forming enamel are amelogenin, ameloblastin, and enamelin. These proteins are proteolytically cleaved following their secretion. Some of the cleavage products accumulate in the enamel layer, while others are either degraded or reabsorbed by ameloblasts ${ }^{56}$.

During the secretory stage, enamel proteins are being secreted along with proteases, creating a complex mixture of enamel matrix constituents. During the transition stage there is an increase in proteolytic activity, and in maturation stage the accumulated enamel proteins nearly disappear from the matrix. The selective proteolysis of enamel proteins is a major factor in determining the make-up/composition of the enamel matrix ${ }^{56}$. It is not difficult to understand that changes in enzymatic protein degradation by the genetic defects of proteins or proteinases can result in the pathological changes during the enamel formation ${ }^{39}$.

\section{AMELOGENESIS IMPERFECTA}

Amelogenesis imperfecta (AI) is a group of inherited defects of dental enamel formation that show both clinical and genetic heterogeneity ${ }^{49}$. In its mildest form, AI causes discoloration, while in the most severe presentation the enamel is hypomineralized causing it to be abraded from the teeth shortly after their emergence into the mouth ${ }^{63}$. Both the primary and permanent dentitions were affected. Enamel findings in AI are highly variable, ranging from deficient enamel formation to defects in the mineral and protein content ${ }^{46}$. The four main types of AI were described as follows: hipoplastic, hypomineralized, hypomaturation and with taurodontism ${ }^{11}$.

The AI phenotypes vary widely depending on the specific gene involved, the location and type of mutation, and the corresponding putative change at the protein level ${ }^{27}$. Different inheritance patterns such as X-linked, autosomal dominant and autosomal recessive types have been reported and 14 subtypes of AI were recognized ${ }^{39}$.

The distribution of AI types is known to vary in different populations ${ }^{46}$, suggesting allele frequency differences between ethnics ${ }^{9}$. The combined prevalence of all forms of AI has been reported as 1:14000 in the U.S. ${ }^{62}$, 1:8000 in Israel ${ }^{9}$ and 1:4000 in Sweden ${ }^{58}$. The autosomal dominant AI is most prevalent in the United States and Europe, as is the autosomal recessive AI in the Middle East ${ }^{9,}{ }^{2}$. Different mutations in genes that transcribe principal matrix proteins and proteinases of enamel have been associated with different phenotype of AI.

\section{AMELOGENIN}

and AMELY Yp11 genes, is considered to be critical for normal enamel thickness and structure ${ }^{15}$. Amelogenin is the most abundant, accounting for more than $90 \%$ of total enamel protein ${ }^{16}$, while ameloblastin and enamelin account for about $5 \%$ and $2 \%$ of total protein, respectively ${ }^{56}$. It is initially secreted by ameloblasts, as a 25-kDa nascent protein, which has a high degree of polarity determined by its highly hydrophilic C terminal teleopeptide. The teleopeptide seems to be processed rapidly by specific endoproteinases and/or carboxy-proteinases to form a 23-kDa amelogenin molecule intermediate $^{17}$. A 20-kDa amelogenin stable form results from either transient 23-kDa intermediates or a single cleavage of $25-k D a$ parent amelogenins ${ }^{15}$. The accumulation of 20-kDa amelogenin in enamel indicates a relative slowdown in further protein hydrolysis ${ }^{51}$. This fragment is cleaved to produce both an insoluble tyrosine rich amelogenin peptide (TRAP) and a soluble $13-\mathrm{kDa}$ fragment ${ }^{51}$. Therefore, amelogenin is degraded extracellularly and enzimatically, resulting in a number of smaller peptides which produce a skeleton for mineralization and crystal formation of the enamel. Amelogenin protein aggregates referred to as nanospheres support and protect growing crystals, inhibit intercrystallyte fusions, and create channels for ion transport ${ }^{51}$.

Amelogenin is thought to form a scaffold for enamel crystallites and to controll their growth ${ }^{15}$, but its exact functions are not fully known ${ }^{25}$.

At least 14 mutations - 5 nucleotide substitutions; 7 small deletions; and 2 gross deletions - have been described in amelogenin gene. A 5kb deletion removes 5 of the 7 exons of the amelogenin gene. The remaining coding sequence is limited to 18 codons; 16 of these encode the signal peptide. This mutation destroys the function of the amelogenina protein completely, producing enamel of normal thickness but poorly mineralized and severe discoloration ${ }^{36}$.

The 9bp deletion in exon 2 coding for the signal sequence resulted in hypoplastic enamel that is normally mineralized, but of reduced thickness ${ }^{37}$. This phenotype is compatible with a mutation affecting the transport of a protein, required of the formation of enamel ${ }^{37}$. Deletions of a C-nucleotide in different codons cause a premature stop codon and loss of the C-terminus of the protein, leading to the production of hypoplastic and/or hypomineralization AI, and the symptoms can vary among affected members of same family ${ }^{1,}$ 2, 24, 25, 33, 38 . Several substitution mutations have also been reported at different locations; two substitutions, C to A and $\mathrm{A}$ to $\mathrm{T}$, were described in exon $6^{10,25,50}$, and produce hypomaturation AI. Both might have a similar effect on the function of the amelogenin protein ${ }^{25}$. Other three substitutions, $\mathrm{C}$ to $\mathrm{T}$ in exon $5, \mathrm{G}$ to $\mathrm{T}$ in exon $6^{38}$ and $\mathrm{G}$ to $\mathrm{A}^{25}$ has also been described in families with AI.

Although the transcriptionally active amelogenin gene is found on both human $\mathrm{X}$ and $\mathrm{Y}$ chromosomes. There are no reports of amelogenesis imperfecta with mutations in the $\mathrm{Y}$ amelogenin. This may be explained by the fact that the $\mathrm{Y}$ chromosome accounts for only approximately $10 \%$ of amelogenin transcripts ${ }^{55}$.

Amelogenin, the protein product of the AMELX Xq22 


\section{AMELOBLASTIN}

Ameblastin, also known as amelin, is expressed by the enamel-producing ameloblast cells ${ }^{19}$. It is a tooth-specific glycoprotein, which represents the most abundant nonamelogenin enamel matrix protein ${ }^{19}$. Low levels of this protein are also expressed by Hertwing's epithelial root sheath $^{20}$ and preodontoblast ${ }^{18}$, but its role in dentin and cementum formation has not been established. The protein is found inside rounded structures at the distal end of the cell body and near the secretion pole of ameloblasts. It was also present near the dentin-enamel junction ${ }^{42}$.

The ameloblastin gene is located in chromosome 4, within the critical region for local hypoplastic $\mathrm{AI}^{41}$. Recently it was reported that transgenic mice overexpressing ameloblastin in ameloblasts resemble amelogenesis imperfecta, suggesting the importance of ameloblastin in enamel formation ${ }^{47}$. In ameloblastin-null mice, the dental epithelium differentiates into enamel-secreting ameloblasts, but the cells detach from the matrix surface at the secretory stage and lose cell polarity. Mutant ameloblasts resume proliferation and accumulate to form multiple cell layers, producing abnormal, unstructured, calcified matrix. Ameloblastin binds specifically to ameloblasts and inhibits cell proliferation of mutant ameloblasts. In mutant teeth, ameloblasts regain some early phenotypes of undifferentiated dental epithelial cells, and the abnormalities occur when the cells detach. This results indicate that ameloblastin is a key adhesion molecule for enamel formation and suggest that ameloblastin plays an important role by binding to, and maintaining the differentiated phenotype of secretory ameloblasts ${ }^{23}$.

\section{ENAMELIN}

Enamelin, the largest enamel extracellular matrix protein, was initially identified by Fukae, et al. ${ }^{22}$ (1993). It is produced by ameloblasts, initially during the secretory stage concentrating near the Tomes processes. Much lower levels of enamelin expression have been observed in dental pulp, presumably secreted by odontoblasts, and along the forming $\operatorname{root}^{31}$. Immunohistochemistry combined with Western blot analyses shows that intact enamelin (186 kDa) and the large enamelin cleavage products ( $155 \mathrm{kDa}, 142 \mathrm{kDa}, 89 \mathrm{kDa}$ ) are present only near the enamel surface and do not accumulate in the matrix ${ }^{28}$. All of these proteins contain the original enamelin $\mathrm{N}$-terminus, since enamelin, like amelogenin, is processed by successive cleavages from its $\mathrm{C}$-terminus. The smaller polypeptides from the enamelin C-terminal half appear to undergo successive cleavages or are re-absorbed into ameloblasts, which prevents their accumulation in the deeper enamel layers. The 32-kDa enamelin is resistant to further proteolytic digestion and accumulates in the rod and interrod enamel probably bound to the mineral, while the extreme $\mathrm{N}$ terminus does not bind mineral and concentrates in the sheath space, along with $\mathrm{N}$-terminal polypeptides from ameloblastina. Proteolysis allows enamelin cleavage products to accumulate in different parts of the enamel matrix, and determines their relative abundance. Some enamelin cleavage products appear to be insoluble. The $32-\mathrm{kDa}$ enamelin may be released from themass of insoluble enamel protein by proteolytic cleavage, freeing it to bind enamel crystallites, potentially regulating their shape or habit ${ }^{6}$. Enamelysin (MMP-20) is the predominant proteolytic activity in the secretory-stage enamel matrix ${ }^{54}$, and is assumed to catalyze the processing of enamelin. Enamelysin is inactive against the $32-\mathrm{kDa}$ enamelin, but the $32-\mathrm{kDa}$ enamelin can be degraded by KLK-4, the main degradative matrix enzyme that is expressed throughout the maturation stage.

Enamelin is present in small amounts and undergoes a series of proteolytic cleavages to generate several polypeptides that are thought to participate in enamel crystal nucleation and extension, and the regulation of crystal habit ${ }^{22,30}$.

The enamelin gene has been mapped on chromosome 4 as ameloblastin gene (only $15 \mathrm{~kb}$ separate these genes), suggesting that this region could contain a cluster of genes encoding enamel proteins. Recently, enamelin gene mutations have been identified in autosomal dominant forms of hypoplastic $\mathrm{AI}^{27,32,43,49}$. The first reported human enamelin mutation was a splice donor site of intron 7 single base substitution, which resulted in a severe form of thin and smooth hypoplastic $\mathrm{AI}^{49}$. Observed in United Kingdom families with autossomal dominant AI and, because occurs at the beginning of the intron following the sixth coding exon, it is difficult to predict the effect of this mutation on the enamelin protein structure.

A substitution in exon 4, introduced a premature stop codon, was described in Swedish families ${ }^{44}$. This milder form of AI, known clinically as autosomal-dominant local hypoplastic AI, accounts for $27 \%$ of the autosomally inherited cases in Northern Sweden ${ }^{31}$. Most recently, a splice donor site mutation after enamelin codon 196 was shown to cause autosomal-dominant hypoplastic AI (Kida, et al. ${ }^{32}$, 2002). There are normally $6 \mathrm{Gs}$ at the end of coding exon 7 , which are followed by a 7th $G$ at the beginning of the adjacent intron. One of these Gs was deleted in a Japanese family with AI. If the splice donor site function were preserved in the mutant condition, the deletion would shift the reading frame at the start of the last coding exon. The affected members of the family showed hypoplastic enamel in both their deciduous and permanent teeth that resulted in a yellowish appearance and hypersensitivity to cold stimuli. This same mutation has recently been characterized in a family from Australia ${ }^{27}$.

\section{PROTEINASES}

Different proteinases, serving different functions, are expressed during stages of amelogenesis ${ }^{56}$. These proteinases are believed to regulate the enamel matrix protein processing that ultimately defines the structure and composition of enamel ${ }^{5}$. The predominant proteinases are matrix metalloproteinase-20 in secretory enamel matrix and kallikrein-4 in the mature stage ${ }^{39,21}$. 


\section{ENAMELYSIN (MMP-20)}

MMP-20, also known as enamelysin, was originally identified by Bartlett, et al. ${ }^{4}$ (1996). This enzyme is expressed by ameloblasts and the odontoblasts of the dental papilla ${ }^{7}$. Low levels of MMP-20 expression were observed in the pulpar organ ${ }^{3}$. No other intact physiologically normal tissue is known to express MMP-20 $0^{8}$. Therefore, MMP-20 is considered a tooth-specific metalloproteinase. MMP-20 expression was observed in pathologic tissues such as in calcifying odontogenic cysts ${ }^{59}$, odontogenic tumors ${ }^{60}$ and tongue carcinoma ${ }^{61}$.

MMP-20 primary structure includes a signal peptide, propeptide domain, catalytic domain, and hemopexin-like domain ${ }^{56}$. This enzyme can be detected on zymography with 41 and $45 \mathrm{kDa}^{5}$. Catalytic domain fragments were observed with 21 and $25 \mathrm{kDa}^{12}$.

Enamelysin is secreted into the enamel matrix in its developmental stages — secretory and transition ${ }^{4,5,21}$. This enzymes accounts for most of the proteolytic activity of the enamel matrix. Because enamelysin is present in the mineralizing front, it is thought to initiate the hydrolysis of the enamel matrix proteins allowing the crystals to grow in length but not in width or thickness 5 . During this process much of the enamel matrix is removed and the enamel crystallites grow to achieve approximately $40-60 \%$ mineral per volume ${ }^{52}$.

This proteinase is thought to be responsible for the processing of the amelogenin protein at the $\mathrm{N}$-terminus, causing the TRAP to form ${ }^{48,54}$. In addition, MMP-20 degrades gelatin, casein, aggrecan, cartilage oligomeric matrix protein $^{54}$, fibronectin, type IV collagen, laminin 1 and 5, and tenascin- ${ }^{61}$.

A solitary point mutation in exon 6 of the amelogenin gene has been reported to cause hypomineralized AI. This mutation is related to the MMP-20 cleavage site and is known to impair the efficiency of its hydrolysis, reducing the formation of TRAP ${ }^{40}$. Mice with null mutation that eliminates MMP-20 activity have a severe phenotype that includes altered amelogenin processing, hypoplastic enamel that delaminates from the dentin, a disorganized prism patter, and a deteriorating enamel organ morphology as development progresses. This demonstrates that MMP-20 plays a critical protein-processing role during enamel development ${ }^{8}$. The human MMP-20 gene locates to chromosome 11, which has not yet been identified as an AI locus; however, the enamelysin defect would likely be autosomal-recessive and, therefore, less prevalent within the population ${ }^{8}$.

\section{KALLIKREIN-4 (KLK-4)}

Kallikrein-4, initially called enamel matrix serine proteinase, is expressed in teeth, testis, breast, colon, thyroid, uterus, central nervous system and skin ${ }^{57,64}$. The specific function of the KLK-4 in these different tissues is not known. While only KLK-4 has been found in enamel, all other tissues studied have been shown to express multiple kallikrein genes $^{57}$.

During tooth formation, KLK-4 is secreted by both the dentin-forming odontoblasts and the enamel-forming ameloblasts ${ }^{45}$. Its expressions in enamel start abruptly in the transition stage of amelogenesi ${ }^{29}$. Kallikrein- 4 is thought to be the major enzyme responsible for the degradation of enamel proteins during maturation stage, and has been shown to cleave amelogenin ${ }^{53}$.

Kallikrein-4 is secreted as an inactive zymogen of 230 amino acids that can be activated by MMP-20 through the removal of a 6-amino-acid propeptide ${ }^{53}$. It has six disulfide bridges and three potential N-linked glycosylation sites ${ }^{56}$. The characteristic triad of the catalytic amino acids is conserved between species and believed to be critical to its proteolytic function ${ }^{34}$.

KLK-4 is expressed from a gene on chromosome $19^{14}$. Recent studies have shown that kallikrein mutation in association with autosomal recessive hypomaturation $\mathrm{AI}^{26}$, indicating that the normal KLK-4 function is critical for enamel mineralization. The loss of KLK-4 function primarily affects the maturation stage of enamel development inhibiting the growth of enamel crystallites affecting the final deposition of an additional $15-20 \%$ mineral $^{26}$.

\section{CONCLUSION}

Enamel formation requires the expression of multiple genes that transcribes matrix proteins and proteinases needed to control the complex process of crystal growth and mineralization. Mutations in the amelogenin, enamelin, and kallikrein-4 genes have been demonstrated to result in different types of AI. A number of other genes critical to enamel formation have been identified and proposed as candidates for AI, including ameloblastin ${ }^{35}$, tuftelin ${ }^{13}$ and enamelysin ${ }^{4}$. AI can also be caused by an alteration in a gene that is neither known nor considered to be a major contributor to enamel formation. Continued mutational analysis of families with AI will allow a comprehensive standardized nomenclature system to be developed for this group of disorders that will include molecular delineation as well as a mode of inheritance and phenotype.

\section{REFERENCES}

1- Aldred MJ, Crawford PJ, Roberts E, Thomas NS. Identification of a nonsense mutation in the amelogenin gene (AMELX) in a family with X-linked amelogenesis imperfecta (AIH1). Hum Genet. 1992 Dec;90(4):413-6.

2- Aldred MJ, Hall RK, Kilpatrick N, Bankier A, Savarirayan R, Lamande SR, Lench NJ, Crawford PJ. Molecular analysis for genetic counselling in amelogenesis imperfecta. Oral Dis. 2002 Sep;8(5):24953.

3- Bartlett JD, Ryu OH, Xue J, Simmer JP, Margolis HC. Enamelysin mRNA displays a developmentally defined pattern of expression and encodes a protein which degrades amelogenin. Connect Tissue Res. 1998;39(1-3):101-9; discussion 141-9. 
4- Bartlett JD, Simmer JP, Xue J, Margolis HC, Moreno EC. Molecular cloning and mRNA tissue distribution of a novel matrix metalloproteinase isolated from porcine enamel organ. Gene. 1996 Dec 12;183(1-2):123-8.

5- Bartlett JD, Simmer JP. Proteinases in developing dental enamel. Crit Rev Oral Biol Med. 1999;10(4):425-41.

6- Brookes SJ, Lyngstadaas SP, Robinson C, Shore RC, Wood SR, Kirkham J. Enamelin compartmentalization in developing porcine enamel. Connect Tissue Res. 2002;43(2-3):477-81.

7- Caterina J, Shi J, Sun X, Qian Q, Yamada S, Liu Y, Krakora S, Bartlett JD, Yamada Y, Engler JA, Birkedal-Hansen H, Simmer JP. Cloning, characterization, and expression analysis of mouse enamelysin. J Dent Res. 2000 Sep;79(9):1697-703.

8- Caterina JJ, Skobe Z, Shi J, Ding Y, Simmer JP, Birkedal-Hansen H, Bartlett JD. Enamelysin (matrix metalloproteinase 20)-deficient mice display an amelogenesis imperfecta phenotype. J Biol Chem. 2002 Dec 20;277(51):49598-604. Epub 2002 Oct 21.

9- Chosack A, Eidelman E, Wisotski I, Cohen T. Amelogenesis imperfecta among Israeli Jews and the description of a new type of local hypoplastic autosomal recessive amelogenesis imperfecta. Oral Surg Oral Med Oral Pathol. 1979 Feb;47(2):148-56.

10- Collier PM, Sauk JJ, Rosenbloom SJ, Yuan ZA, Gibson CW. An amelogenin gene defect associated with human X-linked amelogenesis imperfecta. Arch Oral Biol. 1997 Mar;42(3):235-42.

11- Crawford PJ, Aldred MJ. X-linked amelogenesis imperfecta. Presentation of two kindreds and a review of the literature. Oral Surg Oral Med Oral Pathol. 1992 Apr;73(4):449-55.

12- DenBesten PK, Punzi JS, Li W. Purification sequencing of a $21 \mathrm{kDa}$ and $25 \mathrm{kDa}$ bovine enamel metalloproteinase. Eur J Oral Sci. 1998;106:345-9

13- Deutsch D, Palmon A, Fisher LW, Kolodny N, Termine JD, Young MF. Sequencing of bovine enamelin ("tuftelin") a novel acidic enamel protein. J Biol Chem. 1991 Aug 25;266(24):16021-8.

14-DuPont BR, Hu CC, Reveles X, Simmer JP. Assignment of serine protease 17 (PRSS17) to human chromosome bands 19q13.3—>q13.4 by in situ hybridization. Cytogenet Cell Genet. 1999;86(3-4):212-3.

15- Fincham AG, Lau EC, Simmer J, Zeichner-David M Amelogenin biochemistry-form and function. Amsterdam: Elsevier Science, 1992:187-201.

16- Fincham AG, Moradian-Oldak J, Simmer JP. The structural biology of the developing dental enamel matrix. J Struct Biol. 1999 Jun 30;126(3):270-99. Review.

17- Fincham AG, Moradian-Oldak J. Comparative mass spectrometric analyses of enamel matrix proteins from five species suggest a common pathway of post-secretory proteolytic processing. Connect Tissue Res. 1996;35(1-4):151-6.

18- Fong CD, Cerny R, Hammarstrom L, Slaby I. Sequential expression of an amelin gene in mesenchymal and epithelial cells during odontogenesis in rats. Eur J Oral Sci. 1998 Jan;106 Suppl $1: 324-30$.

19- Fong CD, Hammarstrom L, Lundmark C, Wurtz T, Slaby I. Expression patterns of RNAs for amelin and amelogenin in developing rat molars and incisors. Adv Dent Res. 1996 Nov;10(2):195-200.

20- Fong CD, Slaby I, Hammarstrom L. Amelin: an enamel-related protein, transcribed in the cells of epithelial root sheath. J Bone Miner Res. 1996 Jul;11(7):892-8.
21- Fukae M, Tanabe T, Uchida T, Lee SK, Ryu OH, Murakami C, Wakida K, Simmer JP, Yamada Y, Bartlett JD. Enamelysin (matrix metalloproteinase-20): localization in the developing tooth and effects of $\mathrm{pH}$ and calcium on amelogenin hydrolysis. J Dent Res. 1998 Aug;77(8):1580-8.

22- Fukae M, Tanabe T, Uchida T, Yamakoshi Y, Shimizu M. Enamelins in the newly formed bovine enamel. Calcif Tissue Int. 1993 Oct;53(4):257-61.

23- Fukumoto S, Kiba T, Hall B, Iehara N, Nakamura T, Longenecker $\mathrm{G}$, et al. Ameloblastin is a cell adhesion molecule required for maintaining the differentiation state of ameloblasts. J Cell Biol. 2004 Dec 6;167(5):973-83.

24- Greene SR, Yuan ZA, Wright JT, Amjad H, Abrams WR, Buchanan JA, Trachtenberg DI, Gibson CW. A new frameshift mutation encoding a truncated amelogenin leads to X-linked amelogenesis imperfecta. Arch Oral Biol. 2002 Mar;47(3):211-7.

25- Hart PS, Aldred MJ, Crawford PJ, Wright NJ, Hart TC, Wright JT. Amelogenesis imperfecta phenotype-genotype correlations with two amelogenin gene mutations. Arch Oral Biol. 2002 Apr;47(4):2615 .

26-Hart PS, Hart TC, Michalec MD, Ryu OH, Simmons D, Hong S, Wright JT. Mutation in kallikrein 4 causes autosomal recessive hypomaturation amelogenesis imperfecta. J Med Genet. 2004 Jul;41(7):545-9.

27- Hart PS, Michalec MD, Seow WK, Hart TC, Wright JT. Identification of the enamelin (g.8344delG) mutation in a new kindred and presentation of a standardized ENAM nomenclature. Arch Oral Biol. 2003 Aug;48(8):589-96.

28- Hu CC, Fukae M, Uchida T, Qian Q, Zhang CH, Ryu OH, et al. Cloning and characterization of porcine enamelin mRNAs. J Dent Res. 1997 Nov;76(11):1720-9.

29- Hu CC, Hart TC, Dupont BR, Chen JJ, Sun X, Qian Q, et al. Cloning human enamelin cDNA, chromosomal localization, and analysis of expression during tooth development. J Dent Res. 2000 Apr;79(4):912-9.

30- Hu JC, Sun X, Zhang C, Simmer JP. A comparison of enamelin and amelogenin expression in developing mouse molars. Eur J Oral Sci. 2001 Apr;109(2):125-32.

31- Hu JC, Yamakoshi Y. Enamelin and autosomal-dominant amelogenesis imperfecta. Crit Rev Oral Biol Med. 2003;14(6):38798. Review.

32- Kida M, Ariga T, Shirakawa T, Oguchi H, Sakiyama Y. Autosomaldominant hypoplastic form of amelogenesis imperfecta caused by an enamelin gene mutation at the exon-intron boundary. J Dent Res. 2002 Nov;81(11):738-42

33- Kindelan SA, Brook AH, Gangemi L, Lench N, Wong FS, Fearne J, Jackson Z, Foster G, Stringer BM. Detection of a novel mutation in X-linked amelogenesis imperfecta. J Dent Res. 2000 Dec;79(12):1978-82.

34- Komatsu N, Takata M, Otsuki N, Toyama T, Ohka R, Takehara $\mathrm{K}$, Saijoh K. Expression and localization of tissue kallikrein mRNAs in human epidermis and appendages. J Invest Dermatol. 2003 Sep;121(3):542-9.

35- Krebsbach PH, Lee SK, Matsuki Y, Kozak CA, Yamada KM, Yamada Y. Full-length sequence, localization, and chromosomal mapping of ameloblastin. A novel tooth-specific gene. J Biol Chem. 1996 Feb 23;271(8):4431-5. 
36- Lagerstrom M, Dahl N, Nakahori Y, Nakagome Y, Backman B, Landegren U, Pettersson U. A deletion in the amelogenin gene (AMG) causes X-linked amelogenesis imperfecta (AIH1). Genomics. 1991 Aug;10(4):971-5.

37- Lagerstrom-Fermer M, Nilsson M, Backman B, Salido E, Shapiro L, Pettersson U, Landegren U. Amelogenin signal peptide mutation: correlation between mutations in the amelogenin gene (AMGX) and manifestations of X-linked amelogenesis imperfecta. Genomics. 1995 Mar 1;26(1):159-62.

38- Lench NJ, Winter GB. Characterisation of molecular defects in X-linked amelogenesis imperfecta (AIH1). Hum Mutat. 1995;5(3):251-9.

39- Li W, Gao C, Yan Y, DenBesten P. X-linked amelogenesis imperfecta may result from decreased formation of tyrosine rich amelogenin peptide (TRAP). Arch Oral Biol. 2003 Mar;48(3):17783.

40- Li W, Gibson CW, Abrams WR, Andrews DW, DenBesten PK. Reduced hydrolysis of amelogenin may result in X-linked amelogenesis imperfecta. Matrix Biol. 2001 Jan;19(8):755-60.

41- MacDougall M, DuPont BR, Simmons D, Reus B, Krebsbach P, Karrman C, Holmgren G, Leach RJ, Forsman K. Ameloblastin gene (AMBN) maps within the critical region for autosomal dominant amelogenesis imperfecta at chromosome 4q21. Genomics. $1997 \mathrm{Apr}$ $1 ; 41(1): 115-8$.

42- MacDougall M, Simmons D, Gu TT, Forsman-Semb K, Mardh CK, Mesbah M, Forest N, Krebsbach PH, Yamada Y, Berdal A. Cloning, characterization and immunolocalization of human ameloblastin. Eur J Oral Sci. 2000 Aug;108(4):303-10.

43- Mardh CK, Backman B, Simmons D, Golovleva I, Gu TT, Holmgren G, MacDougall M, Forsman-Semb K. Human ameloblastin gene: genomic organization and mutation analysis in amelogenesis imperfecta patients. Eur J Oral Sci. 2001 Feb;109(1):8-13.

44- Mardh KC, Backman B, Holgren G, Hu JC-C, Simmer JP, ForsmanSemb K. A nonsense mutation in the enamelin gene causes local hypoplastic autossomal dominant amelogenesis imperfecta (AIH2). Hum Mol Genet 2002;11:1069-74.

45- Nagano T, Oida S, Ando H, Gomi K, Arai T, Fukae M. Relative levels of mRNA encoding enamel proteins in enamel organ epithelia and odontoblasts. J Dent Res. 2003 Dec;82(12):982-6.

46- Nusier M, Yassin O, Hart TC, Samimi A, Wright JT. Phenotypic diversity and revision of the nomenclature for autosomal recessive amelogenesis imperfecta. Oral Surg Oral Med Oral Pathol Oral Radiol Endod. 2004 Feb;97(2):220-30.

47- Paine ML, Wang HJ, Luo W, Krebsbach PH, Snead ML. A transgenic animal model resembling amelogenesis imperfecta related to ameloblastin overexpression. J Biol Chem. 2003 May 23;278(21):19447-52. Epub 2003 Mar 25.

48- Palosaari H, Pennington CJ, Larmas M, Edwards DR, Tjaderhane L, Salo T. Expression profile of matrix metalloproteinases (MMPs) and tissue inhibitors of MMPs in mature human odontoblasts and pulp tissue. Eur J Oral Sci. 2003 Apr;111(2):117-27.

49- Rajpar MH, Harley K, Laing C, Davies RM, Dixon MJ. Mutation of the gene encoding the enamel-specific protein, enamelin, causes autosomal-dominant amelogenesis imperfecta. Hum Mol Genet. 2001 Aug 1;10(16):1673-7

50- Ravassipour DB, Hart PS, Hart TC, Ritter AV, Yamauchi M, Gibson C, Wright JT. Unique enamel phenotype associated with amelogenin gene (AMELX) codon 41 point mutation. J Dent Res. 2000 Jul;79(7):1476-81.
51- Robinson C, Brookes SJ, Shore RC, Kirkham J. The developing enamel matrix: nature and function. Eur J Oral Sci. 1998 Jan;106 Suppl 1:282-91.

52- Robinson C, Kirkham J, Hallsworth AS. Volume distribution and concentration of protein, mineral and water in developing bovine enamel. Arch Oral Biol. 1988;33(3):159-62.

53- Ryu O, Hu JC, Yamakoshi Y, Villemain JL, Cao X, Zhang C, Bartlett JD, Simmer JP. Porcine kallikrein-4 activation, glycosylation, activity, and expression in prokaryotic and eukaryotic hosts. Eur J Oral Sci. 2002 Oct;110(5):358-65.

54- Ryu OH, Fincham AG, Hu CC, Zhang C, Qian Q, Bartlett JD, Simmer JP. Characterization of recombinant pig enamelysin activity and cleavage of recombinant pig and mouse amelogenins. J Dent Res. 1999 Mar;78(3):743-50.

55- Salido EC, Yen PH, Koprivnikar K, Yu LC, Shapiro LJ. The human enamel protein gene amelogenin is expressed from both the $\mathrm{X}$ and the Y chromosomes. Am J Hum Genet. 1992 Feb;50(2):30316.

56- Simmer JP, Hu JC. Expression, structure, and function of enamel proteinases. Connect Tissue Res. 2002;43(2-3):441-9. Review.

57- Stephenson SA, Verity K, Ashworth LK, Clements JA. Localization of a new prostate-specific antigen-related serine protease gene, KLK4, is evidence for an expanded human kallikrein gene family cluster on chromosome 19q13.3-13.4. J Biol Chem. 1999 Aug 13;274(33):23210-4.

58- Sundell S, Koch G. Hereditary amelogenesis imperfecta. I. Epidemiology and clinical classification in a Swedish child population. Swed Dent J. 1985;9(4):157-69

59- Takata T, Zhao M, Nikai H, Uchida T, Wang T. Ghost cells in calcifying odontogenic cyst express enamel-related proteins. Histochem J. 2000 Apr;32(4):223-9.

60- Takata T, Zhao M, Uchida T, Wang T, Aoki T, Bartlett JD, Nikai $\mathrm{H}$. Immunohistochemical detection and distribution of enamelysin (MMP-20) in human odontogenic tumors. J Dent Res. 2000 Aug;79(8):1608-13.

61- Vaananen A, Srinivas R, Parikka M, Palosaari H, Bartlett JD, Iwata $\mathrm{K}$, et al. Expression and regulation of MMP-20 in human tongue carcinoma cells. J Dent Res. 2001 Oct;80(10):1884-9.

62- Witkop C, Sauk JJ. Heritable defects of enamel. In Oral Facial Genetics. St Louis: CV Mosby Company, 1976:151-226.

63- Wright JT, Deaton TG, Hall KI, Yamauchi M. The mineral and protein content of enamel in amelogenesis imperfecta. Connect Tissue Res. 1995;32(1-4):247-52.

64- Yousef GM, Luo LY, Diamandis EP. Identification of novel human kallikrein-like genes on chromosome 19q13.3-q13.4. Anticancer Res. 1999 Jul-Aug;19(4B):2843-52. 